\title{
Role of Neurokinin 3 Receptors in Supraoptic Vasopressin and Oxytocin Neurons
}

\author{
Heather E. Howe, Suwit J. Somponpun, and Celia D. Sladek \\ Department of Physiology and Biophysics, University of Colorado Health Sciences Center, Denver, Colorado 80262
}

\begin{abstract}
Neurokinin 3 receptors (NK3-Rs) are expressed in the supraoptic nucleus (SON), and SON is innervated by substance P (SP)-expressing A1 neurons in the medulla. Because SP stimulates vasopressin (VP) and oxytocin release from explants of the hypothalamoneurohypophyseal system (HNS), two hypotheses were tested: (1) SP-stimulated VP release is mediated by NK3-Rs, and (2) stimulation of the A1 pathway by hypotension activates SON NK3-Rs. Senktide, an NK3-R agonist, stimulated VP release from HNS explants, but neither a neurokinin 1 receptor antagonist [L732,138 ( $\mathrm{N}$-acetyl-L-tryptophan 3,5-bis(tri-fluoromethyl)benzyl ester)] nor two NK3-R antagonists (SB222200 and SB235375) prevented SP-stimulated VP release. Because the affinity of these antagonists for rat NK-Rs may limit their efficacy, NK3-R internalization was used to assess the ability of SP to activate SON NK3-Rs. Senktide, SP, or vehicle was microinjected above SON. The brain was perfused $5 \mathrm{~min}$ after injection and stained for NK3-R immunoreactivity. Using confocal microscopy, the number of NK3-R-immunoreactive (-IR) endosomes was counted in a $5.6^{2} \mu$ region of cytoplasm in SON neurons. Senktide, but not SP or vehicle, significantly increased the number of NK3-R-IR endosomes in the cytoplasm. When hypotension was induced with hydralazine, NK3-R internalization was observed within $5 \mathrm{~min}(p<0.005)$. A decrease in cytoplasmic NK3-R immunoreactivity was observed within 15 min of hypotension. Unexpectedly, both senktide and hypotension resulted in translocation of NK3-R-IR immunoreactivity to the nucleus. Thus, although these studies do not identify SP as the NK3-R ligand, they do provide evidence for hypotensioninduced release of an endogenous tachykinin in SON and evidence suggesting a role for NK3-Rs in transcription regulation.
\end{abstract}

Key words: oxytocin; receptor; substance P; supraoptic; vasopressin; neurokinin 3

\section{Introduction}

The tachykinin peptide family includes substance $\mathrm{P}$ (SP), neurokinin $\mathrm{A}$, and neurokinin $\mathrm{B}(\mathrm{NKB})$. These peptides interact with three neurokinin receptors (NK1-R, NK2-R, and NK3-R). Substance $\mathrm{P}$, neurokinin $\mathrm{A}$, and $\mathrm{NKB}$ exhibit the highest affinity for NK1-R, NK2-R, and NK3-R, respectively, but each ligand can activate the other receptor types if present at a sufficiently high concentration. These receptors are G-protein-coupled receptors (GPCRs), all of which can activate both phosphotidylinositol hydrolysis and the cAMP signal cascade (Nakajima et al., 1992).

NK3-Rs are highly expressed in the supraoptic nucleus (SON) and the paraventricular nucleus (PVN) (Ding et al., 1996, 1999; Shughrue et al., 1996; Mileusnic et al., 1999). Activation of these receptors by intracerebroventricular injection of $\mathrm{NKB}$ or a selective NK3-R agonist, senktide, results in Fos expression in SON and PVN (Ding et al., 2000; Smith and Flynn, 2000; Spitznagel et al., 2001), as well as antidiuresis (Eguchi et al., 1996) and peripheral vasopressin (VP) and oxytocin (OT) release (Polidori et al., 1989; Bealer and Flynn, 2003); however, the endogenous ligand

Received Aug. 2, 2004; revised Sept. 15, 2004; accepted Sept. 23, 2004

This work was supported by National Institutes of Health Grant R01-NS44835 to C.D.S. The technical assistance of Steve Fadul in the University of Colorado Health Science Center Light Microscopy Facility is gratefully acknowledged. We thank Drs. David Brooks and Douglas W. Hay of GlaxoSmithKline for their help in obtaining the NK3-receptor antagonists and their advice on the use of the antagonists.

Correspondence should be addressed to Dr. Celia D. Sladek, Department of Physiology, University of Colorado Health Science Center, 4200 East Ninth Avenue, Denver, C0 80262. E-mail: celia.sladek@uchsc.edu.

D01:10.1523/JNEUROSCI.3164-04.2004

Copyright $\odot 2004$ Society for Neuroscience $\quad$ 0270-6474/04/2410103-08\$15.00/0 for these receptors and their importance to physiological stimulation of VP and OT release from the neurohypophysis has not been determined. Immunocytochemical studies reported a few NKB-immunoreactive (-IR) fibers in SON (Lucas et al., 1992), and one study reported NKB-positive cells in SON (Hatae et al., 2001); however, although immunoreactivity to a 30-residue peptide of the NKB protein precursor was reported in SON (Marksteiner et al., 1992; Hatae et al., 2001), NKB-IR cell bodies and mRNA were not detected in SON with in situ hybridization (Warden and Young, 1988; Lucas et al., 1992; Marksteiner et al., 1992; Merchenthaler et al., 1992). The presence of NKBexpressing cells adjacent to SON (Marksteiner et al., 1992) may account for NKB mRNA detected by Western blot (Hatae et al., 2001).

In contrast, SON and PVN are innervated by SP fibers (Holzbauer et al., 1984; Sladek and Armstrong, 1985; Bittencourt et al., 1991). These fibers originate principally from the A1 catecholamine neurons in the ventral medulla, and $15-25 \%$ of these neurons express SP (Bittencourt et al., 1991). This pathway transmits information about decreases in blood volume and pressure (Cunningham and Sawchenko, 1991). The report that SP is reduced in SON after hemorrhage (Feuerstein et al., 1984) supports release of SP in response to activation of the A1 pathway by hypotension. SP is a potent stimulus for $\mathrm{VP}$ and OT release with 10 $\mu \mathrm{M}$ SP inducing a large and sustained increase in VP and OT release from explants of the hypothalamo-neurohypophyseal system (Kapoor and Sladek, 2001; Juszczak and Stempniak, 2003). 
Because the magnocellular neurons express NK3-Rs but not NK1-Rs (Nakaya et al., 1994), and because SP is an agonist for NK3-Rs, SP may be the endogenous ligand for the NK3-Rs in SON.

NK3-R antagonists were used to test the hypothesis that NK3-Rs mediate SP stimulation of VP release from hypothalamoneurohypophyseal system (HNS) explants. NK3-R internalization was used to test the hypothesis that a tachykinin is released when the Al catecholamine pathway is activated by hypotension.

\section{Materials and Methods \\ Animals}

Male Sprague Dawley rats [Crl:CD(SD)Br (Charles Rivers Laboratories, Wilmington, MA)] were maintained on a $12 \mathrm{hr}$ light/dark cycle with lights on at 6 A.M. and ambient temperature at $21 \pm 1^{\circ} \mathrm{C}$. Standard rat chow and water were available ad libitum throughout the experiment. All protocols used were performed in accordance with the National Institutes of Health Guidelines for the Care and Use of Laboratory Animals and were approved by the Institutional Animal Care and Use Committee of the University of Colorado Health Science Center.

\section{HNS explant perifusion experiments}

Male rats (125-149 gm) were decapitated and explants of the HNS were prepared as described previously (Sladek and Knigge, 1977). The brain and pituitary were removed from the skull using a caudal approach to ensure that the pituitary stalk was intact. The anterior pituitary was removed under a dissecting microscope. After the meninges (dura mater and arachnoid) was gently removed, a triangular block of tissue was removed from the ventral hypothalamus by cutting rostral to the optic chiasm, lateral to either side of the median eminence, and undercutting at a depth of 1-2 $\mathrm{mm}$. The explants included the magnocellular neurons of the SON with their axonal projections extending through the median eminence and terminating in the neurohypophysis. Using a dissecting microscope, the explants were examined to ensure that the neurohypophyseal stalk was intact. Also included in the explant are the suprachiasmatic, arcuate, and ventral portions of the ventromedial, preoptic, and periventricular nuclei as well as the organum vasculosum of the lamina terminalis.

Each explant was placed in a $500 \mu \mathrm{l}$ perifusion chamber, maintained at $37^{\circ} \mathrm{C}$ in the multiple microchamber unit (Cellex Biosciences, Minneapolis, MN), and perifused with F12 nutrient mixture (Sigma, St. Louis, MO) fortified with $20 \%$ fetal calf serum, $1 \mathrm{mg} / \mathrm{ml}$ glucose, $50 \mu \mathrm{U} / \mathrm{ml}$ penicillin, $50 \mu \mathrm{g} / \mathrm{ml}$ streptomycin, and $1 \times 10-{ }^{4} \mathrm{M}$ bacitracin. Bacitracin was added to the medium to prevent hormone degradation (Sladek and Armstrong, 1987). The final osmolality of the culture medium was 295-300 mOsm $/ \mathrm{kg} \mathrm{H}_{2} \mathrm{O}$. The medium was warmed $\left(37^{\circ} \mathrm{C}\right)$ and gassed $\left(95 \% \mathrm{O}_{2}, 5 \% \mathrm{CO}_{2}\right)$ immediately before being placed in the explant chamber. Six explants were perifused simultaneously at a rate of $\sim 2.0 \mathrm{ml} / \mathrm{hr}$, and outflow from the chambers was collected individually in $20 \mathrm{~min}$ intervals using a six-place fraction collector kept in a refrigerator $\left(4^{\circ} \mathrm{C}\right)$ for subsequent measurement of VP or OT concentration. Radioimmunoassay (RIA) was used to determine VP concentration in these samples.

Hormone release was allowed to stabilize for $4 \mathrm{hr}$ before exposure to any experimental conditions. Subsequently, explants were perifused with basal medium or the indicated concentrations of SP (AnaSpec, San Jose, CA) or senktide (Tocris Cookson, Ellisville, MO). Explants were exposed to an NK1 antagonist, $\mathrm{N}$-acetyl-L-tryptophan 3,5-bis(tri-fluoromethyl) benzyl ester (L732,138) (Sigma) (Cascieri et al., 1994) or one of two NK3-R antagonists, SB222200 and SB235375 (Sarau et al., 2000; Hay et al., 2002) (generously provided by GlaxoSmithKline, Research Triangle Park, NC), 30 min before the addition of SP. Drugs and peptides were dissolved directly into the medium with the exception of SB222200, which was dissolved in dimethylsulfoxide (DMSO). Control explants were exposed to the same concentrations of DMSO ( $n=3-6$ per group).

Radioimmunoassay. VP concentration in the perifusate was determined by RIA as described previously (Kapoor and Sladek, 2001). The antisera was generated in conjunction with Arnel Products (Brooklyn, NY) and used at a final dilution of 1:100,000. The buffer was $0.1 \mathrm{M} \mathrm{PBS,}$ $\mathrm{pH} 7.6$, with $1 \mathrm{mg} / \mathrm{ml}$ bovine serum albumin and $1 \mathrm{mg} / \mathrm{ml}$ sodium azide. The assay was performed on 100 and $50 \mu \mathrm{l}$ aliquots of each fraction
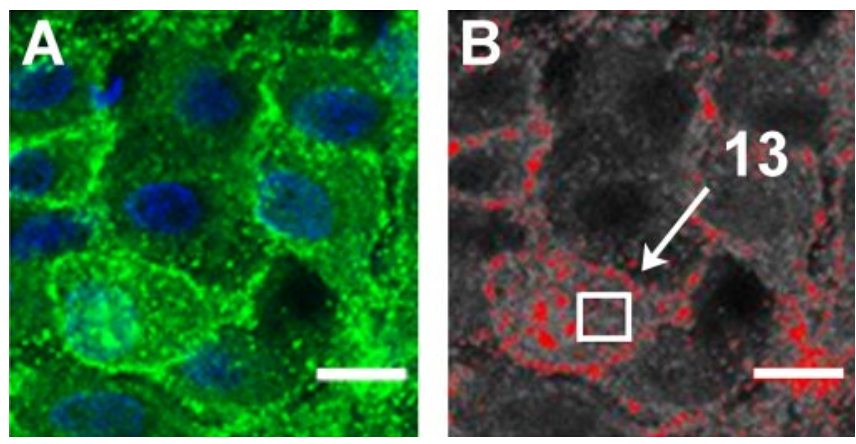

Figure 1. Demonstration of the technique used to quantitate NK3-R internalization. The original image $(A)$ was converted to grayscale $(B)$, and a uniform threshold was applied (red) to determine the immunoreactive regions to be counted. The immunoreactive spots within a $5.6^{2}$ $\mu \mathrm{m}$ region (white box) were counted. In this example, 13 endosomes were counted. Scale bar, $10 \mu \mathrm{m}$.

collected from each explant. The standards and samples were incubated for $72 \mathrm{hr}$ at $4^{\circ} \mathrm{C}$ in the presence of 5000 counts per minute of ${ }^{125} \mathrm{I}$ arginine vasopressin (NEN, Boston, MA). Antibody-bound VP was separated from free hormone with dextran-coated charcoal, and the amount of ${ }^{125} \mathrm{I}-\mathrm{VP}$ in the pellet was determined with a gamma counter. The picograms per milliliter were obtained by comparing samples with a standard curve of known concentrations of VP. All samples from a given experiment were assayed at the same time. The minimum sensitivity was $1.0 \mathrm{pg}$ per tube for VP.

Statistical analysis. As mentioned previously, each explant was allowed to equilibrate for $4 \mathrm{hr}$ before exposure to drugs. Basal hormone release was calculated for each explant as the mean hormone release at the end of this equilibration period. Hormone content is expressed as a percentage of this basal value. Results are expressed as mean \pm SEM. Statistical significance was determined on $\log 10$-transformed data by ANOVA with repeated measures followed by simple main effect analysis to establish specific group differences at individual time points. Level of significance was set to $p<0.05$.

\section{NK3 receptor internalization}

Surgical procedures. Male rats (275-300 gm) were anesthetized intraperitoneally with avertin $(0.4 \mathrm{mg}$ of 2,2,2 tribromoethanol/gm body weight, prepared in saline; Sigma Aldrich). Venous and arterial femoral catheters were implanted and exteriorized at the base of the neck. The catheters

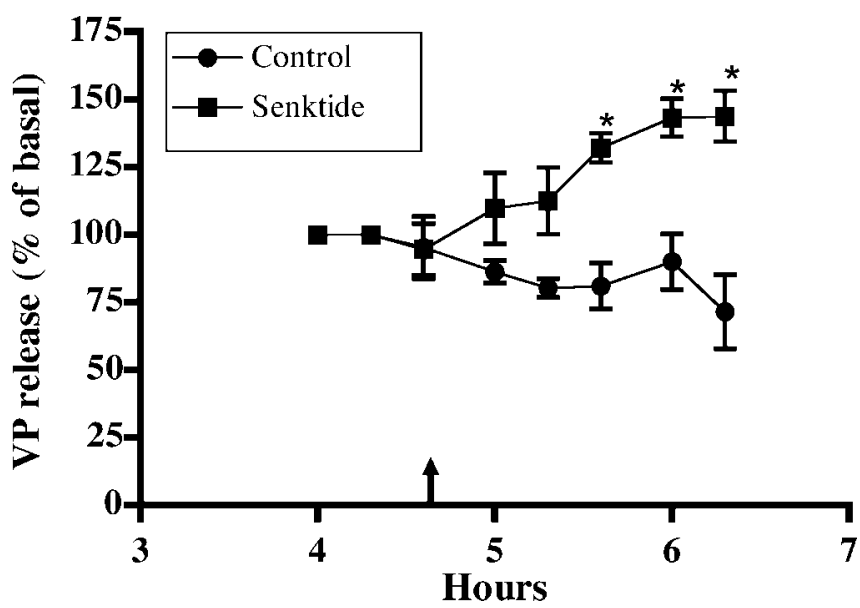

Figure 2. Effect of an NK3-R agonist, senktide, on VP release from HNS explants. After a $4 \mathrm{hr}$ equilibration period, senktide $(0.1 \mu \mathrm{M})$ was added to the perifusate of one group of HNS explants. Perifusate was collected at 20 min intervals for determination of VP content by RIA. VP content was increased significantly in the perifusate from the senktide-exposed explants compared with the controls ( ${ }^{*} p<0.05$ ) for the duration of the exposure. Basal release for control group was $156 \pm 61 \mathrm{pg} / \mathrm{ml}(n=4)$; for the senktide group, it was $158 \pm 45 \mathrm{pg} / \mathrm{ml}(n=5)$. 
were composed of a 6 inch piece of PE50 polyethylene tubing melted to either a $40 \mathrm{~mm}$ (arterial) or a $30 \mathrm{~mm}$ (venous) piece of PE10 tubing. Arterial catheters were filled with $200 \mathrm{U} / \mathrm{ml}$ heparanized saline to maintain patency of the line. In some animals, a cannula (23 gauge) was implanted unilaterally above the SON using stereotaxic coordinates (1.0 $\mathrm{mm}$ caudal, $1.4 \mathrm{~mm}$ lateral, $9.0 \mathrm{~mm}$ ventral relative to bregma). The cannula was held in place with dental acrylic and two small screws. Surgeries were performed $3 \mathrm{~d}$ before the experiment.

Blood pressure measurements. On the morning of the experiment, the arterial catheter was connected to a pressure transducer, and arterial pressure was monitored for $15 \mathrm{~min}$. The animal was then anesthetized with urethane [1.25 gm urethane/kg body weight (Sigma Aldrich); delivered via the arterial catheter], and arterial pressure was monitored for 1 additional hour before the following protocols.

$S P$-senktide protocol. One hour after urethane was administered, a 0.2 $\mu \mathrm{l}$ microinjection of substance $\mathrm{P}[100 \mu \mathrm{M}$ in PBS (Tocris Cookson); $n=$ 10], senktide [79 $\mu \mathrm{M}$ in PBS (Tocris Cookson); $n=9$ ], or PBS $(n=12)$ was administered through the brain cannula using a $5 \mu$ l Hamilton syringe. Five minutes after the injection, rats were perfused transcardially with $80 \mathrm{ml}$ of $0.1 \mathrm{M}$ PBS followed by $150 \mathrm{ml}$ of $4 \%$ paraformaldehyde (PFA) in $0.1 \mathrm{M}$ phosphate buffer. After perfusion, the brain was removed and placed in $30 \%$ sucrose in $4 \%$ PFA for $3 \mathrm{hr}$ and then in $30 \%$ sucrose in PBS for at least $3 \mathrm{~d}$.

Hypotension experiment. After blood pressure was allowed to stabilize for $1 \mathrm{hr}$ under urethane anesthesia, hydralazine $(10 \mathrm{mg} / \mathrm{kg}$; Sigma Aldrich) or saline was administered via the venous catheter. At 5, 15, or 60 min after this treatment, rats were perfused transcardially with $80 \mathrm{ml}$ of $0.1 \mathrm{M}$ PBS followed by $150 \mathrm{ml}$ of $4 \%$ PFA in $0.1 \mathrm{M}$ phosphate buffer. After perfusion, the brain was removed and placed in 30\% sucrose in $4 \%$ PFA for $3 \mathrm{hr}$ and then in $30 \%$ sucrose in PBS for at least $3 \mathrm{~d}(n=5$ per group except the 5 min PBS group, which was $n=4$ ).

Histology. Brains were sectioned at $30 \mu \mathrm{m}$ with a cryostat and stored in a cryoprotectant solution (30\% sucrose, $30 \%$ ethylene glycol, $1 \%$ polyvinylpyrrolidone in $0.1 \mathrm{M}$ phosphate buffer) at $-20^{\circ} \mathrm{C}$ until they were processed for staining. All rinses and incubations except the antibody incubation were performed at room temperature. On the day of staining, all sections were rinsed in $0.1 \mathrm{M}$ PBS with $0.2 \%$ Triton-X (PBS/TriX) for $1 \mathrm{hr}$. They were then incubated in $0.5 \%$ sodium borohydride prepared in $0.1 \mathrm{M}$ PBS for $20 \mathrm{~min}$ followed by $1 \mathrm{hr}$ of rinsing in PBS/TriX. Next, the sections were incubated in $0.3 \% \mathrm{H}_{2} \mathrm{O}_{2}$ prepared in water followed by 30 min of rinsing in PBS/TriX. The sections were then placed in $1.5 \%$ goat serum in PBS/TriX for $1 \mathrm{hr}$. They were then incubated in a rabbit polyclonal antibody to the NK3-R [NB300-102 (Novus Biologicals, Littleton, CO); 1:10,000 dilution] for $72 \mathrm{hr}$ at $4^{\circ} \mathrm{C}$. The sections were then rinsed for $30 \mathrm{~min}$ and incubated in goat anti-rabbit IgG antibody labeled with Alexa Fluor 488 (Molecular Probes, Eugene, OR; 1:400 dilution in PBS/TriX) for $1 \mathrm{hr}$. After a $30 \mathrm{~min}$ rinse in PBS/TriX, the sections were placed in 300 nм 4',6-diamidino-2-phenylindole, dihydrochloride (DAPI) (Molecular Probes) for $5 \mathrm{~min}$. The sections were then rinsed in $0.1 \mathrm{M}$ PBS, mounted on poly-lysine-treated slides, and coverslipped with ProLong Antifade (Molecular Probes). The NK3-R antibody was raised against a synthetic peptide from the C terminus of the rat NK3-R (aa 438-452). Staining was not observed when the primary antibody was omitted.

Image collection. Confocal images were acquired using a Zeiss LSM 510 NLO laser scanning confocal microscope with argon $(488 \mathrm{~nm})$ and titanium:sapphire $(795 \mathrm{~nm})$ lasers, using a $63 \times$ oil objective. For each image, $\mathrm{Z}$ stacks of 12 images were obtained with each image taken $2.4 \pm 0.1 \mathrm{~m}$ apart.

Quantification of NK3-IR internalization. An investigator, blind to the animal's blood pressure status or drug treatment, quantified internalization using NIH ImageJ software. First, each image was converted to gray scale. As demonstrated in Figure 1, after application of a uniform threshold, the number of endosomes in a $5.6^{2} \mathrm{~mm}$ region within the cytoplasm was counted. In the SP-senktide injection experiments, 10 cells were analyzed in two sections through each SON. Thus 40 cells were analyzed in each rat (20 from the injected side and 20 from the noninjected side). The locations of these cells spanned the dorsal-ventral and medial-lateral extent of the nucleus (see Fig. 5D,E, for examples of visual field); therefore, both VP and OT neurons were included in the analysis. The
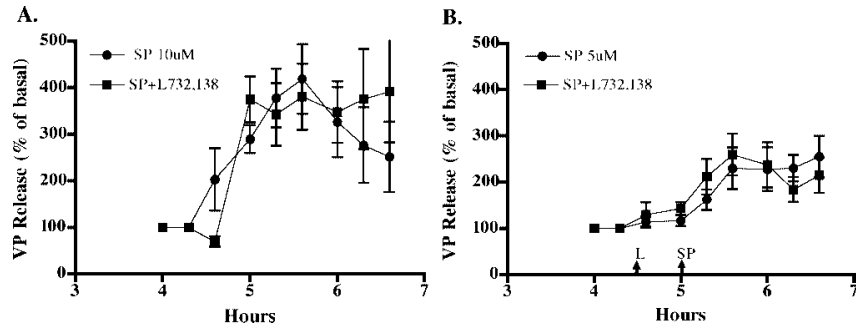

Figure 3. Effect of NK1-R antagonist, L732,138, on SP-stimulated VP release. The antagonist did not significantly alter the VP response to either $10 \mu \mathrm{M}(A)$ or $5 \mu \mathrm{m}$ (B) SP. Basal release for these groups of explants was as follows: $A, 46 \pm 9 \mathrm{pg} / \mathrm{ml}$ for SP alone and $45 \pm 12 \mathrm{pg} / \mathrm{ml}$ for $\mathrm{SP}+\mathrm{L} 732,138 ; B, 88 \pm 12 \mathrm{pg} / \mathrm{ml}$ for SP alone and $99 \pm 18 \mathrm{pg} / \mathrm{ml}$ for SP $+\mathrm{L} 732,138 . n=5$ or 6 per group.

sections through SON that were analyzed on the injected side were within $400 \mu \mathrm{m}$ of the tip of the injection cannulas (see Fig. $5 E$ for an example of a cannula placement immediately above SON). This was not significantly different among the PBS, SP, and senktide groups. In the hypotension experiment, 30 cells were analyzed in three sections through SON in each animal. We chose to sample a consistent area $\left(5.6^{2} \mu \mathrm{m}\right)$ within each cell to eliminate the differences in cytoplasmic area between cells. Cells were selected randomly from the visual field (see Fig. $5 D, E$ ), but they had to meet the following criteria. The entire cell had to be present in the section as determined from the examination of the $\mathrm{z}$-stack, and the z-section analyzed had to include the cell nucleus and a sufficient area of cytoplasm to accommodate the $5.6^{2} \mathrm{~mm}$ counting square shown in Figure 1 .

Statistical analysis. Student's paired $t$ test was used to compare endosome counts between the injected and noninjected SONs. Nonpaired $t$ tests were used to compare internalization between the saline- and hydralazine-treated rats. One-way ANOVA was used to assess the time course of the internalization response to hydralazine-induced hypotension.

\section{Results \\ HNS explant perifusion experiments}

\section{Effect of NK3-R agonist}

Senktide was used as a selective NK3-R agonist to evaluate the effect of NK3-R activation on VP release from HNS explants. As shown in Figure 2, senktide $(0.1 \mu \mathrm{M})$ significantly increased VP release compared with control explants perifused with basal me$\operatorname{dium}(F=18.82 ; p<0.005)$. The response was sustained for the duration of exposure $(\sim 1.5 \mathrm{hr})$. Higher concentrations of senktide did not result in a greater increases in VP release (data not shown).
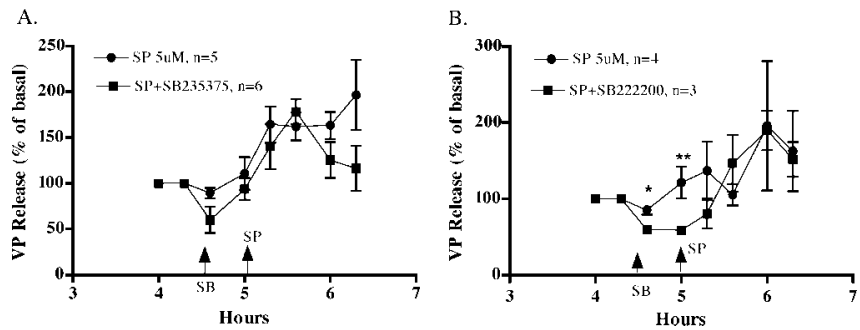

Figure 4. Effect of NK3-R antagonists, SB235375 ( $A$ ) and SB222200 ( $B$ ), on SP-stimulated VP release. The antagonists $(500 \mu \mathrm{m})$ were added to the perifusate 30 min before SP $(5 \mu \mathrm{M})$. Neither antagonist prevented SP-stimulated VP release. Although there was a trend for both antagonists to reduce basal VP release before the addition of SP, only one time point met significance with independent Student's $t$ test $\left({ }^{*} p<0.02 ;{ }^{* *} p=0.054\right)$. Basal release was as follows: $A, 48.6 \pm 16.1 \mathrm{pg} / \mathrm{ml}$ for SP alone, $68.8 \pm 33 \mathrm{pg} / \mathrm{ml}$ for SP+SB235375; $B, 25 \pm 5.5$ $\mathrm{pg} / \mathrm{ml}$ for SP alone, $29.4 \pm 6.3 \mathrm{pg} / \mathrm{ml}$ for SP + SB222200. 

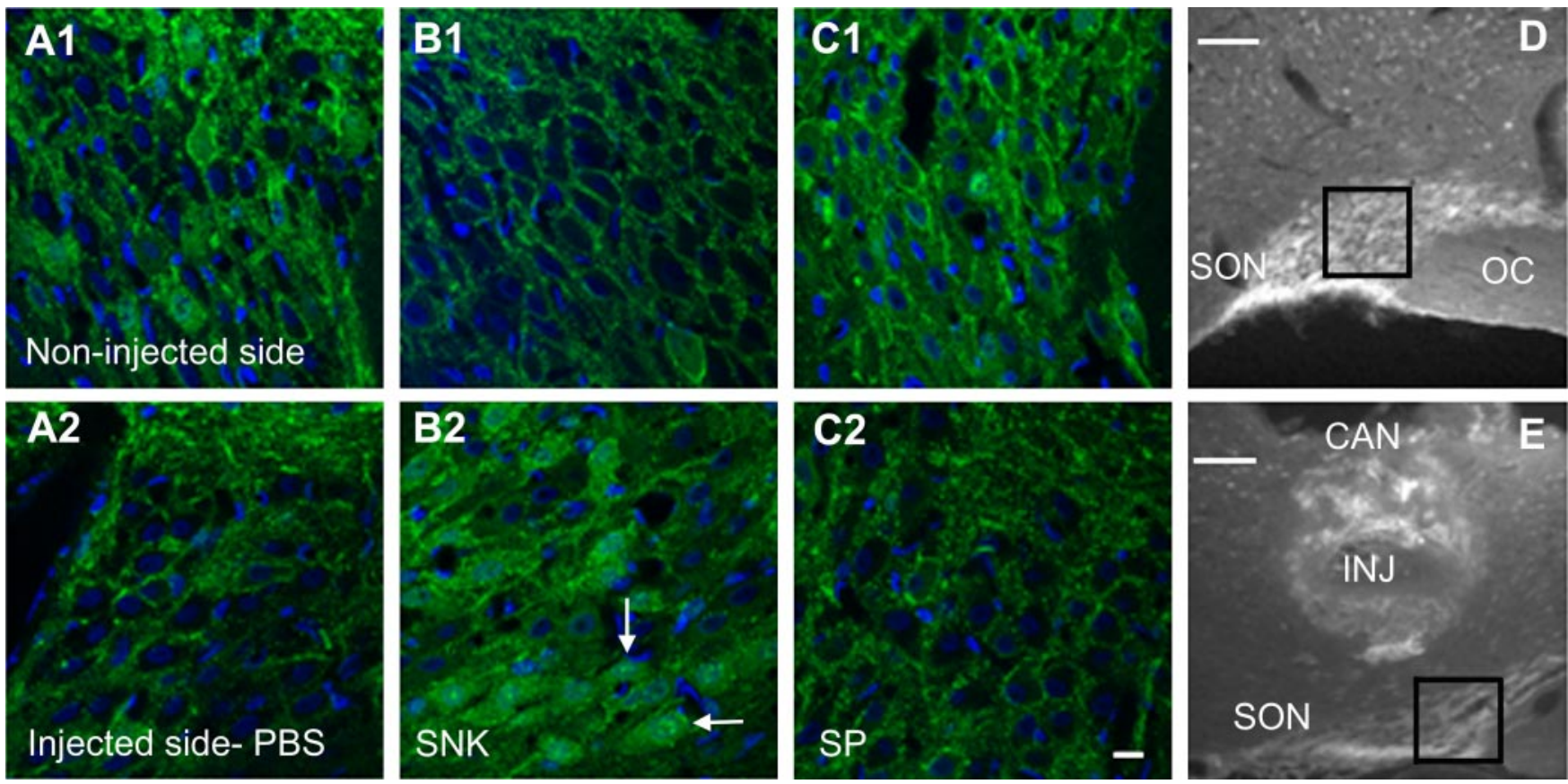

Figure 5. Immunocytochemical localization of NK3 immunoreactivity (green) in SON of rats injected with PBS, senktide, or SP immediately above the SON on one side of the brain is shown in $A-C$. In the PBS-injected rats, there is prominent localization of the NK3 immunoreactivity to the cell membrane in both the injected (A2) and noninjected (A7) sides. In the senktide-injected rat, the noninjected side (B1) displays membrane localization, whereas the injected side (B2) displays NK3 immunoreactivity internalized to the cytoplasm. NK3 immunoreactivity is localized to the membrane in both the SP-injected side $(C 2)$ and the noninjected side $(C 1)$. The cell nuclei were stained with DAPI (blue). White arrows indicate punctate NK3 immunoreactivity localized to the nucleus after the senktide injection (B2). Nuclear localization was not observed after theSP injection (C2). D shows the region of SON depicted in B2. Eshows a representative cannula (CAN) placement with the injector (INJ) extending to immediately above SON. The cannula tract is not visible in $D$ but was present in the section rostral to this level. Scale bars: $A-C, 10 \mu \mathrm{m} ; D, E, 100 \mu \mathrm{m}$.

\section{Effect of NK1-R antagonist}

Because SP has the highest affinity for NK1-Rs, the ability of an NK1-R antagonist, L732,138, to block SP-stimulated VP release was evaluated. The antagonist was added to the perifusate $30 \mathrm{~min}$ before SP. As shown in Figure 3, SP caused a dose-dependent increase in VP release comparable with that observed previously (Kapoor and Sladek, 2001), with $5 \mu \mathrm{M}$ SP resulting in a sustained increase of $\sim 250 \%$ of basal and $10 \mu \mathrm{M}$ SP causing a $300-400 \%$ increase. These increases are statistically significant $\left(F_{5 \mu \mathrm{M}}=10.8\right.$, $\left.p<0.0001 ; F_{10 \mu \mathrm{M}}=10.04, p<0.0001\right)$ and were sustained for the duration of exposure to SP. L732,138 $(100 \mu \mathrm{M})$ did not significantly alter the response to either 5 or $10 \mu \mathrm{M}$ SP, suggesting that the SP effect is not caused by activation of NK1-Rs.

\section{Effect of NK3-R antagonists}

Because NK3-Rs are expressed in SON and because SP can act as a ligand for NK3-Rs, albeit with lower affinity than for NK1-Rs (Nakajima et al., 1992), the ability of NK3-R antagonists to block SP stimulation of VP release was evaluated. Two NK3-R antagonists, SB235375 and SB222200, were used. As shown in Figure 4, the VP response to $5 \mu \mathrm{M}$ SP was not significantly altered by either antagonist. The NK3-R antagonists were added to the perifusate $30 \mathrm{~min}$ before SP to assess the effect of the antagonists on basal VP release. Although there was a tendency for VP release to be lower in the NK3-R antagonists groups before the addition of SP, this did not result in a significant difference between the groups or a significant interaction between time and treatment in the twoway, repeated-measure ANOVA in either experiment, and only one data point met the criteria for a statistical significant difference by independent Student's $t$ test $(4.6 \mathrm{hr}$ in the SB222200) (Fig. $4 B)\left({ }^{*} p<0.05\right)$. Thus, although VP release can be stimulated by an NK3-R agonist (senktide), the experiments with

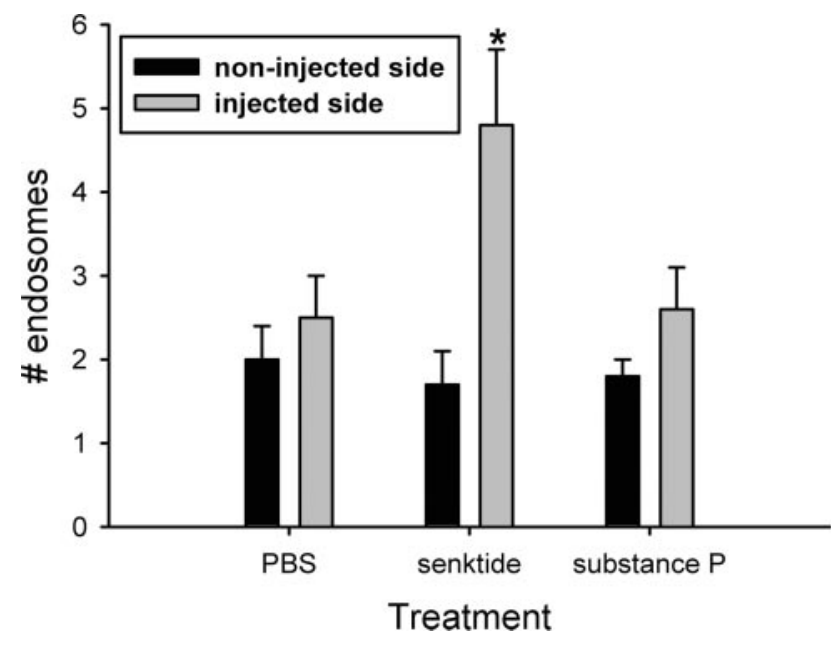

Figure 6. Quantification of the effect of $P B S$, senktide, and SP injections immediately above SON on the cytoplasmic localization of NK3-IR endosomes. Senktide, but not PBS nor SP, increased the number of endosomes on the injected side $\left({ }^{*} p=0.015\right)$. Data are expressed as mean \pm SEM number of endosomes in a $5.6^{2} \mu \mathrm{m}$ region of cytoplasm per neuron per animal. $n=9-12$ animals per group.

NK3-R antagonists do not provide evidence that SP-stimulated VP release is mediated by NK3-Rs.

\section{NK3 receptor internalization in SON}

NK1-Rs and NK3-Rs, as well as several other G-protein-coupled receptors, undergo rapid endocytosis on ligand binding (Kobilka, 1992; Colin et al., 2002). Internalization of NK receptors has been used as an index of neurokinin release in response to 


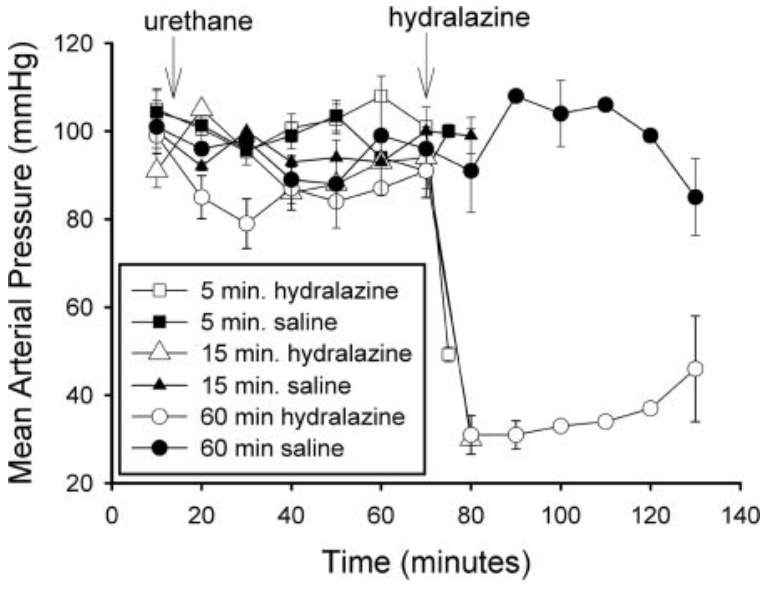

Figure 7. Effect of hydralazine on mean arterial blood pressure. Hydralazine rapidly induced hypotension that was sustained for as long as $60 \mathrm{~min}$. Urethane anesthesia did not alter blood pressure. Animals were anesthetized $1 \mathrm{hr}$ in advance of hydralazine administration so that the brain could be perfused shortly after the induction of hypotension.

physiological and pharmacological stimuli (Colin et al., 2002; Sabino et al., 2002). We used NK3-R internalization to assess the hypotheses that (1) SP acts as a ligand for NK3-Rs in SON and (2) $\mathrm{NK} 3-\mathrm{Rs}$ in SON are activated in response to hypotension.

Effect of local injection of senktide or SP on NK3-R localization Local injection of senktide $(79 \mu \mathrm{M})$, but not PBS or SP $(100 \mu \mathrm{M})$, induced an increase in the number of NK3-IR endosomes in the cytoplasm in SON neurons at 5 min after injection. As shown in Figure 5, NK3 immunoreactivity was localized primarily to the cell membrane of SON neurons on the noninjected side of the brains. It was also localized to the cell membrane on the side injected with PBS and SP. Quantification of the number of cytoplasmic endosomes is shown in Figure 6. Senktide-injected rats displayed significantly more internalized endosomes on the side of the injection compared with the noninjected side ( $p=0.015)$, but SP did not increase cytoplasmic localization of NK3 immunoreactivity. Because cells located throughout the dorsal-ventral extent of SON were analyzed in each section of SON (Fig. 5D,E), it is probable that senktide induced NK3-R internalization in both VP and OT neurons.

Effect of hydralazine-induced hypotension on NK3-R localization The effect of urethane anesthesia and saline or hydralazine injections on mean arterial blood pressure is shown in Figure 7. Blood pressure was not altered by the urethane or saline injections but decreased to $49 \pm 2 \mathrm{mmHg}$ by $5 \mathrm{~min}$ and to $30 \pm 2 \mathrm{mmHg}$ by 15 min after hydralazine. It remained low without additional hydralazine for $1 \mathrm{hr}$ after the injection. Heart rate was not significantly altered by the hydralazine injection. This probably reflects inhibition of the baroreflex by urethane (Shimokawa et al., 1998), because in previous studies using conscious rats, heart rate was increased after hydralazine (Stocker et al., 2000). As seen in Figure 8 , the NK3 immunoreactivity was primarily localized to the cell membrane in the SON of saline-injected rats at all time points. There was a significant increase in cytoplasmic localization of the NK3 immunoreactivity at $5 \mathrm{~min}$ after hydralazine (Figs. 8A2, 9) $(p=0.005)$. Cytoplasmic localization decreased rapidly and was not significantly different from that in salineinjected animals at 15 or 60 min of hydralazine-induced hypotension. It was significantly reduced compared with the $5 \mathrm{~min}$ hypotensive group (Kruskal-Wallis one-way ANOVA on ranks; $H=14.347 ; p=0.014)$. These data indicate that a ligand for the NK3-R is released in response to hydralazine-induced hypotension. Because hydralazine inhibits production of angiotensin II (Stocker et al., 2000), activation of the Al pathway from the caudal ventrolateral medulla to SON is likely to mediate VP and OT release induced by hydralazine (Day and Sibbald, 1989; Schiltz et al., 1997).

\section{Nuclear localization of NK3 immunoreactivity}

After senktide injection above SON and for up to $1 \mathrm{hr}$ after hydralazine-induced hypotension, NK3
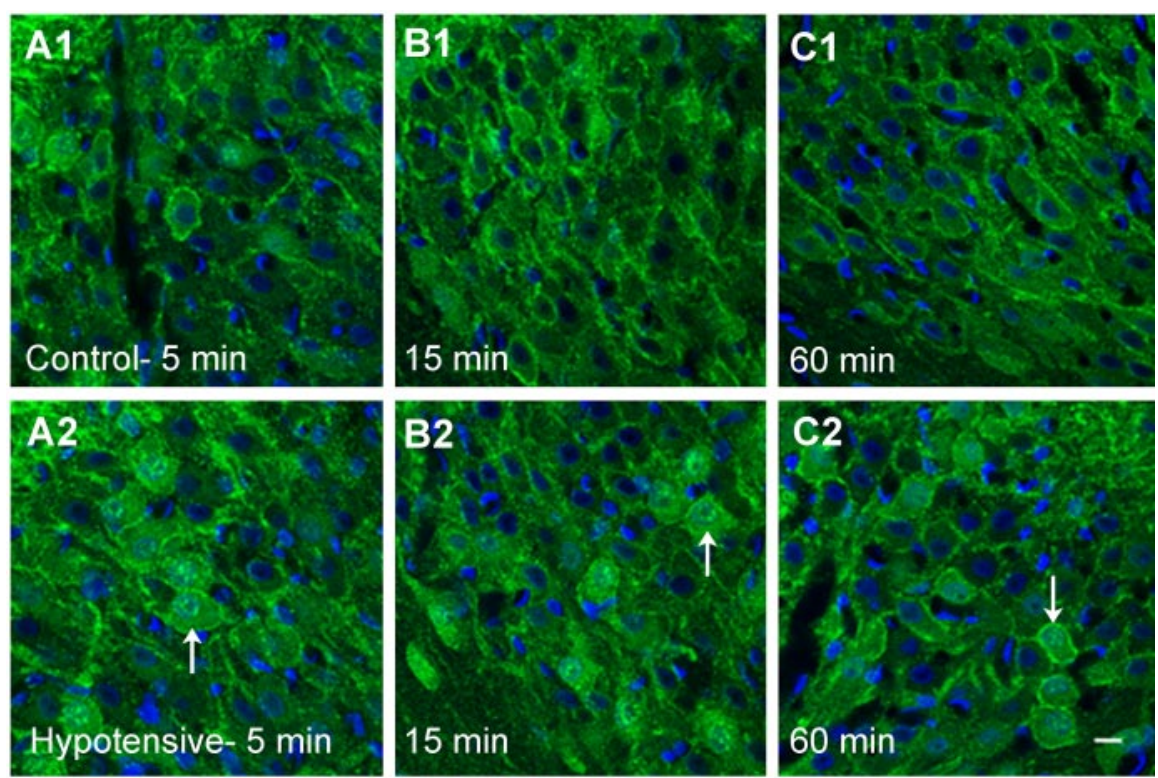
immunoreactivity was observed in the nuclei of SON neurons (Figs. 5B2, 8A2-C2). DAPI staining of the nucleus, collection of confocal images through the $z$-axis of the nucleus, and the presence of NK3 immunoreactivity at the level of nucleolus provided evidence that these NK3-IR particles were located within the nucleus and not simply in the perinuclear region. Perinuclear localization of GPCR or incorporation of GPCR into the nuclear envelope is seen as a distinct rim of immunoreactivity around the nucleus in confocal images (Bhattacharya et al., 1999; Gicquiaux et al., 2002). Perinuclear localization of GPCR is a common feature of GPCR sorting after endocytosis (Sorkin and Von Zastrow, 2002), and prostaglandin receptors have been visualized in the nuclear envelope (Bhattacharya et al., 1999). As seen in Figures $5 B 2$ and $8 A 2-C 2$, however, NK3 immunoreactivity did not rim the nucleus, and imaging through the $\mathrm{z}$-plane of the nucleus allowed verification that the immunoreactivity was not above or below the nucleus. Quantitation of NK3-IR nuimmunoreactivity (green) is evident at all time points in the saline-injected, normotensive animals (A1-C1). Five minutes of hypotension induces NK3-R internalization (A2), which is decreased by $15 \mathrm{~min}$ (B2) and remains low after 60 min of hypotension (C2). The nuclei are stained with DAPI (blue). Note the prominent nuclear localization of NK3 immunoreactivity that is evident at $5 \mathrm{~min}$ of hypotension and remains evident at 15 and $60 \mathrm{~min}$ of hypotension (white arrows). Scale bar, $10 \mu \mathrm{m}$.
Figure 8. Localization of NK3-Rs in SON in response to hypotension at 5, 15, and $60 \mathrm{~min}$. Membrane localization of NK3 


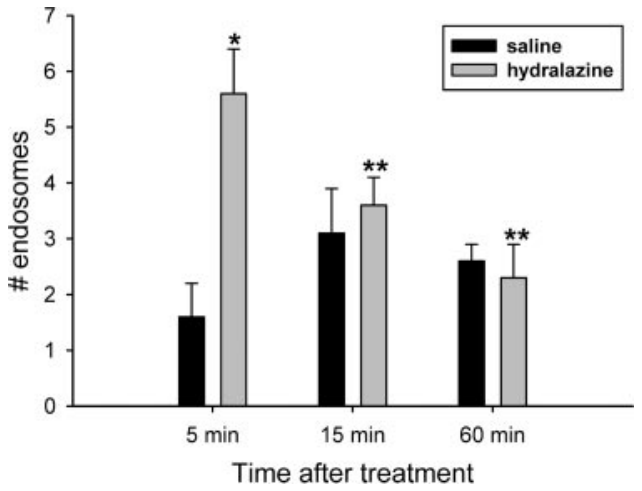

Figure 9. Quantification of the time course of NK3-R internalization during hydralazineinduced hypotension. The number of cytoplasmic NK3-IR endosomes was significantly increased by 5 min of hypotension in hydralazine-treated rats ( $\left.{ }^{*} p=0.005 ; n=5\right)$ compared with normotensive rats $(n=4)$. By $15 \mathrm{~min}$, cytoplasmic NK3 immunoreactivity was significantly decreased $(n=5)$ and remained low after 60 min of hypotension $\left(n=5 ;{ }^{* *} p<0.05\right.$ by post hoc Newman-Keuls analysis).
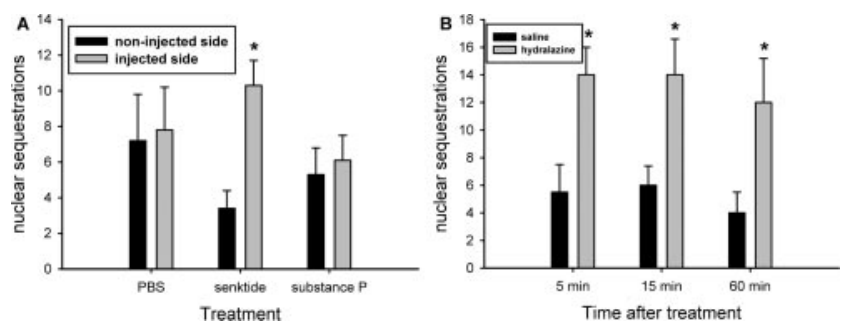

Figure 10. Quantification of nuclear localization of NK3 immunoreactivity. A, After microinjection of senktide, but not PBS and SP, the number of neurons with NK3 immunoreactivity in the nucleus was significantly increased $\left({ }^{*} p=0.002\right.$ injected vs noninjected side). $n=9-12$ animals per group. $B$, Hydralazine-induced hypotension significantly increased the number of neurons with an NK3-IR-positive nucleus at 5, 15, and 60 min compared with saline-injected normotensive animals ( $p=0.02$ at 5 and $15 \mathrm{~min} ; p=0.05$ at $60 \mathrm{~min}$ ). $n=4$ or 5 animals per group.

clear localization was accomplished by counting the number of SON neurons in which NK3-IR particles were confirmed to exist within the nuclear boundaries by examining the z-stack of confocal images through each cell body. As shown in Figure 10, microinjection of senktide, but not PBS or SP, induced nuclear localization of NK3-IR ( $p=0.002$; injected vs noninjected side). There was also a significant increase in the number of NK3positive nuclei at all time points evaluated in the hypotensive animals $(p<0.05)$. These observations suggest that in addition to translocation of NK3-Rs from the cell membrane into cytoplasmic endosomes, there is also translocation into the cell nucleus.

\section{Discussion}

These studies demonstrate that a specific NK3-R agonist, senktide, and a physiological stimulus for VP and OT secretion, hypotension, induce NK3-R activation in SON as evidenced by internalization of NK3 immunoreactivity. In addition, the in vitro studies confirmed the in vivo evidence from other laboratories that activation of NK3-Rs by senktide stimulates VP secretion from the neural lobe (Eguchi et al., 1996). These observations suggest that release of an endogenous tachykinin in SON contributes to hypotension-induced stimulation of VP and OT release; however, the endogenous ligand for the NK3-Rs in SON remains to be identified.

Internalization of NK1-R has been used extensively to study the role of SP in physiological responses (Sabino et al., 2002;
Marvizon et al., 2003). Ligand-induced NK3-R internalization has also been demonstrated (Colin et al., 2002; Schmidlin et al., 2003), but to our knowledge, NK3-R internalization has not been used previously to identify the nature of the neurotransmitter involved in specific physiological responses. In the current studies, rapid internalization of the NK3-R occurred in SON after hydralazine-induced hypotension. Hypotension activates SON neurons and is a potent stimulus for VP and OT release from the neural lobe (Stricker and Verbalis, 1986; Smith and Day, 2003). Although the A1 pathway has been identified as the pathway that carries information about decreases in blood pressure from the brainstem to the SON (Day and Sibbald, 1989), the neurotransmitter(s) responsible for hypotension-stimulated VP release has not been unequivocally identified. The A1 pathway was originally identified as a catecholaminergic pathway, but noradrenergic antagonists do not block activation of SON neurons by hypotension (Day et al., 1990). Furthermore, other neurotransmitters and neuropeptides are colocalized in the Al catecholamine neurons (Blessing et al., 1986; Bittencourt et al., 1991; Day et al., 1993). Because SP is colocalized in $15-25 \%$ of the A1 catecholamine neurons (Bittencourt et al., 1991), it is a candidate for chemical transmission by this pathway. The current finding of hypotension-induced NK3-R internalization is consistent with this possibility.

Ligand-induced internalization of NK3-Rs is mediated by $\beta$-arrestin 2 in NK3-transfected human embryonic kidney 293 cells, resulting in rapid recycling to the cell membrane and resensitization of the cells to an NK3 ligand (Schmidlin et al., 2003). The time course of change in cytoplasmic localization of NK3-Rs in SON neurons induced by hypotension is consistent with rapid resensitization, because a significant increase in cytoplasmic NK3 immunoreactivity was apparent as early as $5 \mathrm{~min}$ after hydralazine, but it returned to basal levels within $15 \mathrm{~min}$. The latter could indicate rapid recycling to the cell membrane, and rapid receptor resensitization is consistent with the continued secretion of VP observed during senktide perfusion of HNS explants; however, translocation of NK3 immunoreactivity to the nucleus was also observed and could contribute to the decrease in cytoplasmic NK3 immunoreactivity observed after $15 \mathrm{~min}$ of hypotension.

The observed translocation of NK3 immunoreactivity to the nucleus was unexpected, because classically, GPCRs are believed to alter cellular processes by initiating signal transduction cascades from the cell membrane. After internalization into endosomes, most GPCRs are either recycled to the membrane resulting in resensitization of the cell to the ligand or transferred to lysosomes for degradation (Kobilka, 1992; Mantyh et al., 1995); however, other GPCRs have been shown to enter the nucleus. These include the angiotensin 1 (AT1) receptor (Lu et al., 1998) as well as the closely related apelin and bombesin 2 receptors (Lee et al., 2004) and the parathyroid hormone receptor (Watson et al., 2000). The fact that nuclear localization of NK3 immunoreactivity was increased by the manipulations that induced NK3 internalization, e.g., senktide injection or hypotension, but not by SP injection, supports the hypothesis that nuclear NK3 immunoreactivity reflects ligand-activated NK3 that is translocated from the cell membrane to the nucleus.

The presence of GPCR in the nucleus raises important questions. How do they get into the nucleus? What is their role in the nucleus? These issues have been considered most extensively for the AT1 receptor (Lu et al., 1998). In considering the first question, the AT1 receptor was found to have a nuclear localization sequence (NLS) in its cytoplasmic C tail (Lu et al., 1998). An NLS is a sequence of amino acids that exists in proteins that are found in the nucleus. The consensus bipartite NLS consists of a 10-12 
amino acid spacer flanked by repeats of basic amino acids [lysine or arginine; K/R-K/R- 10-12 aa spacer $-\mathbf{K} / \mathbf{R}-\mathbf{K} / \mathbf{R}-\mathbf{K} / \mathbf{R}-\mathbf{K} / \mathbf{R}$ (Jans and Hubner, 1996)]. Such a sequence is present in the classic steroid hormone receptors that concentrate in the nucleus and function as transcription factors. It is also observed in other nuclear proteins such as the transcription factor, c-fos, and poly(ADP-ribose) polymerase (Jans and Hubner, 1996). Examination of the NK3 sequence (Buell et al., 1992; Takahashi et al., 1992), revealed a similar sequence in the cytoplasmic $C$ terminus of the rat NK3-R in which the sequence of amino acids 428-446 is RKKRATPRDPSFNGCSRR. In the case of the AT1 receptor, mutations in the NLS prevented nuclear translocation of the receptor ( $\mathrm{Lu}$ et al., 1998). Similar experiments with the NK3-R are required to confirm that the identified sequence functions as an NLS.

Nuclear translocation of NK receptors has not been reported previously despite the extensive studies on the internalization and recycling of these receptors (Grady et al., 1995; Mantyh et al., 1995; McConalogue et al., 1998; Jenkinson et al., 2000; Colin et al., 2002; Sabino et al., 2002; Marvizon et al., 2003). This is not unexpected for the NK1-R because it does not contain a putative NLS (Takeda et al., 1991; Takahashi et al., 1992). The absence of reports of nuclear translocation of NK3 may reflect the cell types evaluated (Jenkinson et al., 2000; Colin et al., 2002), because nuclear localization of the G-protein-coupled apelin receptors has been observed in some cells but not others (Lee et al., 2004). Another possible explanation for variable detection of nuclear translocation of NK3 may be that only fragments of NK3 are translocated to the nucleus. This has been postulated as a mechanism for freeing active portions of membrane-bound receptors for movement into the nucleus (Wells and Marti, 2002). Under this scenario, detection of nuclear NK3-R would be dependent on utilization of an antibody directed at the portion of the molecule that enters the nucleus. It is noteworthy that the antibody used in the current study is directed at the C-terminal region of the NK3-R that includes the putative NLS.

The rapid appearance of NK3 immunoreactivity in the nucleus after senktide injection or hydralazine-induced hypotension as well as its sustained presence throughout $1 \mathrm{hr}$ of hypotension suggests that NK3-Rs may play both early and sustained roles in the regulation of gene expression during stimulation of VP secretion. A role in the regulation of gene transcription has been suggested for nuclear AT1 receptors, because angiotensin II modulation of norepinephrine transporter and tyrosine hydroxylase gene expression is disrupted by blocking AT1 nuclear translocation (Lu et al., 1998); however, further studies are required to demonstrate that nuclear NK3-Rs participate in the regulation of gene expression in SON neurons.

Although SP was considered a likely candidate for the endogenous ligand for the NK3-Rs in SON, the current studies have not identified it as such. NK3-R antagonists did not prevent SP stimulation of VP release from HNS explants, and SP did not induce NK3-R internalization when microinjected in SON. On the other hand, these negative results do not provide conclusive evidence that SP is not an effective endogenous ligand for the NK3-Rs in SON. Because the NK3 antagonists used have a lower affinity for rat NK3-Rs than for human NK3-Rs (Sarau et al., 2000; Hay et al., 2002), it is possible that the 100-fold excess of antagonist was not sufficient to block SP activation of NK3-Rs in the perifusion experiments. Furthermore, because SP has a lower affinity for NK3-Rs than senktide, it is possible that the concentration of SP injected was not sufficient to activate the NK3-Rs. Similarly, the lower affinity of SP for NK3-Rs may explain the absence of SPinduced Fos expression in SON and the lack of a SP-induced increase in plasma VP after intracerebroventricular injection of SP but not senktide at similar concentrations (Polidori et al., 1989; Spitznagel et al., 2001). Another possibility is that SP may activate cellular processes via NK3-Rs independent of inducing receptor internalization. Dissociation between receptor signaling and endocytosis has been shown for morphine activation of $\mu$ opiate receptors (Whistler et al., 1999). The failure of SP to induce NK3 internalization also prevented SP-induced translocation of NK3-R to the nucleus. Thus, if there is a dissociation between SP-induced NK3 signaling and receptor internalization, it would suggest that the potential for NK3 regulation of gene expression is ligand dependent; however, if dissociation between receptor activation and endocytosis occurs with SP activation of NK3-Rs in SON, it would not be universal to NK3-Rs, because incubation of brainstem slices with $5 \mu \mathrm{M}$ SP did induce NK3-R internalization (Colin et al., 2002). Additional endpoints such as calcium imaging may be useful in determining whether SP activates NK3-Rs in SON without inducing receptor internalization.

\section{References}

Bealer SL, Flynn FW (2003) Central neurokinin 3 receptors increase systemic oxytocin release: interaction with norepinephrine. Exp Neurol 184:1027-1033.

Bhattacharya M, Peri K, Ribeiro-da-Silva A, Almazan G, Shichi H, Hou X, Varma DR, Chemtob S (1999) Localization of functional prostaglandin $\mathrm{E}_{2}$ receptors $\mathrm{EP}_{3}$ and $\mathrm{EP}_{4}$ in the nuclear envelope. $\mathrm{J}$ Biol Chem 274:15719-15724.

Bittencourt JC, Benoit R, Sawchenko PE (1991) Distribution and origins of substance P-immunoreactive projections to the paraventricular and supraoptic nuclei: partial overlap with ascending catecholaminergic projections. J Chem Neuroanat 4:63-78.

Blessing WW, Howe PRC, Joh TH, Oliver JR, Willoughby JO (1986) Distribution of tyrosine hydroxylase and neuropeptide Y-like immunoreactive neurons in rabbit medulla oblongata with attention to colocalization studies, presumptive adrenaline-synthesizing perikarya, and vagal preganglionic cells. J Comp Neurol 248:285-300.

Buell G, Schulz MF, Arkinstall SJ, Mauary K, Missotten M, Adami N, Talabot F, Kawashima E (1992) Molecular characterisation, expression and localisation of human neurokinin-3 receptor. FEBS Lett 299:90-95.

Cascieri MA, Macleod AM, Underwood D, Shiao L-L, Ber E, Sadowski S, Yu H, Merchat KJ, Swain CJ, Strader CD, Fong TM (1994) Characterization of the interaction of $\mathrm{N}$-acyl-L-tryptophans benzyl ester neurokinin antagonists with the human neurokinin-1 receptor. J Biol Chem 269:6587-6591.

Colin I, Blondeau C, Baude A (2002) Neurokinin release in the rat nucleus of the solitary tract via NMDA and AMPA receptors. Neuroscience 115:1023-1033.

Cunningham Jr ET, Sawchenko PE (1991) Reflex control of magnocellular vasopressin and oxytocin secretion. Trends Neurosci 14:406-411.

Day TA, Sibbald JR (1989) Al cell group mediates solitary nucleus excitation of supraoptic vasopressin cells. Am J Physiol 257:R1020-R1026.

Day TA, Renaud LP, Sibbald JR (1990) Excitation of supraoptic vasopressin cells by stimulation of the A1 noradrenaline cell group: failure to demonstrate role for established adrenergic or amino acid receptors. Brain Res 516:91-98.

Day TA, Sibbald JR, Khanna S (1993) ATP mediates an excitatory noradrenergic neuron input to supraoptic vasopressin cells. Brain Res 607:341-344.

Ding Y-Q, Shigemoto R, Takada M, Ohishi H, Nakanishi S, Mizuno N (1996) Localization of the neuromedin K receptor (NK3) in the central nervous system of the rat. J Comp Neurol 364:290-310.

Ding Y-Q, Lu B-Z, Guan A-L, Wang D-S, Xu J-Q, Li J-H (1999) Neurokinin $\mathrm{B}$ receptor (NK3)-containing neurons in the paraventricular and supraoptic nuclei of the rat hypothalamus synthesize vasopressin and express fos following intravenous injection of hypertonic saline. Neuroscience 91:1077-1085.

Ding Y-Q, Shi J, Su L-Y, Xu J-Q, Su C-J, Guo X-E, Ju G (2000) Intracerebroventricular injection of senktide-induced Fos expression in vasopressincontaining hypothalamic neurons in the rat. Brain Res 882:95-102.

Eguchi T, Takano Y, Hatae T, Saito R, Nakayama Y, Shigeyoshi Y, Okamura H, Krause JE, Kamiya H (1996) Antidiuretic action of tachykinin NK-3 receptor in the rat paraventricular nucleus. Brain Res 743:49-55. 
Feuerstein G, Helke C, Faden A (1984) Differential changes in substance P and somatostatin in brain nuclei of rats exposed to hemorrhagic shock. Brain Res 300:305-310.

Gicquiaux H, Lecat S, Gaire M, Dieterlen A, Mely Y, Takeda K, Bucher B, Galzi J-L (2002) Rapid internalization and recycling of the human neuropeptide $\mathrm{Y} \mathrm{Y}_{1}$ receptor. J Biol Chem 22:6645-6655.

Grady EF, Garland AM, Gamp PD, Lovett M, Payan DG, Bunnett NW (1995) Delineation of the endocytic pathway of substance P and its seven-transmembrane domain NK1 receptor. Mol Biol Cell 6:509-524.

Hatae T, Nakayama Y, Kawano H, Masuko S (2001) Effects of water deprivation on neurokinin B production by the arginine-vasopressin neurons of hypothalamic paraventricular and supraoptic nuclei. Fukuoka Igaku Zasshi 92:89-98.

Hay DWP, Giardina GAM, Griswold DE, Underwood DC, Kotzer CJ, Bush B, Potts W, Sandhu P, Lundberg D, Foley JJ, Schmidt DB, Martin LD, Kilian D, Legos JJ, Barone FC, Luttmann MA, Grugni M, Raveglia LF, Sarau HM (2002) Nonpeptide tachykinin receptor antagonists. III. SB 235375, a low central nervous system-penetrant, potent and selective neurokinin-3 receptor antagonist, inhibits citric acid-induced cough and airways hyperreactivity in guinea pigs. J Pharmacol Exp Ther 300:314-323.

Holzbauer M, Donnerer J, Holzer P, Schluet W, Lembech F, Sharman DF (1984) Immunoreactive substance $P$ in the tubero-hypophyseal system of the rat: selective decrease in the neural lobe after dehydration and sodium loading. Neurosci Lett 47:23-28.

Jans DA, Hubner S (1996) Regulation of protein transport to the nucleus: central role of phosphorylation. Physiol Rev 76:651-685.

Jenkinson KM, Mann PT, Southwell BR, Furness JB (2000) Independent endocytosis of the $\mathrm{NK}_{1}$ and $\mathrm{NK}_{3}$ tachykinin receptors in neurons of the rat myenteric plexus. Neuroscience 100:191-199.

Juszczak M, Stempniak B (2003) Melatonin inhibits the substance P-induced secretion of vasopressin and oxytocin from the rat hypothalamoneurohypophysial system: in vitro studies. Brain Res Bull 59:393-397.

Kapoor JR, Sladek CD (2001) Substance P and NPY differentially potentiate ATP and adrenergic stimulated vasopressin and oxytocin release. Am J Physiol Regul Integr Comp Physiol 280:R69-R78.

Kobilka B (1992) Adrenergic receptors as models for G protein-coupled receptors. Annu Rev Neurosci 15:87-114.

Lee DK, Lanca J, Cheng R, Nguyen T, Ji XD, Gobeil Jr F, Chemtob S, George SR, O'Dowd BF (2004) Agonist-independent nuclear localization of the apelin, angiotensin $\mathrm{AT}_{1}$, and bradykinin $\mathrm{B}_{2}$ receptors. J Biol Chem 279:7901-7908.

Lu D, Yang H, Shaw G, Raizada MK (1998) Angiotensin II-induced nuclear targeting of the angiotensin type $1\left(\mathrm{AT}_{1}\right)$ receptor in brain neurons. Endocrinology 139:365-375.

Lucas LR, Hurley DL, Drause JE, Harlan JE (1992) Localization of the tachykinin neurokinin B precursor peptide in rat brain by immunocytochemistry and in situ hybridization. Neuroscience 51:317-345.

Mantyh PW, Allen CJ, Ghilardi JR, Rogers SD, Mantyh CR, Liu H, Basbaum AI, Vigna SR, Maggio JE (1995) Rapid endocytosis of a G proteincoupled receptor: substance P-evoked internalization of its receptor in the rat striatum in vivo. Proc Natl Acad Sci USA 91:2622-2626.

Marksteiner J, Sperk G, Krause JE (1992) Distribution of neurons expressing neurokinin $\mathrm{B}$ in the rat brain: immunohistochemistry and in situ hybridization. J Comp Neurol 317:341-356.

Marvizon JCG, Wang X, Matsuka Y, Neubert JK, Spigelman I (2003) Relationship between capsaicin-evoked substance P release and neurokinin 1 receptor internalization in the rat spinal cord. Neuroscience 118:535-545.

McConalogue K, Corvera CU, Gamp PD, Grady EF, Bunnett NW (1998) Desensitization of the neurokinin-1 receptor (NK1-R) in neurons: effects of substance $P$ on the distribution of NK1-R, $G_{\alpha q / 11}$, G-protein receptor kinase-2/3, and $\beta$-arrestin-1/2. Mol Biol Cell 9:2305-2324.

Merchenthaler I, Maderdrut JL, O'Harte F, Conlon JM (1992) Localization of neurokinin $\mathrm{B}$ in the central nervous system of the rat. Peptides 13:815-829.

Mileusnic D, Lee JM, Magnuson DJ, Hejna MJ, Krause JE, Lorens JB, Lorens SA (1999) Neurokinin-3 receptor distribution in rat and human brain: an immunohistochemical study. Neuroscience 89:1269-1290.

Nakajima Y, Tsuchida K, Negishi M, Ito S, Nakanishi S (1992) Direct linkage of three tachykinin receptors to stimulation of both phosphatidylinositol hydrolysis and cyclic AMP cascades in transfected Chinese hamster ovary cells. J Biol Chem 267:2437-2442.

Nakaya Y, Kaneko T, Shigemoto R, Nakanishi S, Mizuno N (1994) Immu- nohistochemical localization of substance P receptor in the central nervous system of the adult rat. J Comp Neurol 347:249-274.

Polidori C, Saija A, Perfumi M, Costa G, De Caro G, Massi M (1989) Vasopressin release induced by intracranial injection of tachykinins is due to activation of central neurokinin-3 receptors. Neurosci Lett 103:320-325.

Sabino MAC, Honore P, Roger SD, Mach DB, Luger NM, Mantyh PW (2002) Tooth extraction-induced internalization of the substance P receptor in trigenimal nucleus and spinal cord neurons: imaging the neurochemistry of dental pain. Pain 95:175-186.

Sarau HM, Griswold DE, Bush B, Potts W, Sandhu P, Lundberg D, Foley JJ, Schmidt DB, Webb EF, Martin LD, Legos JJ, Whitmore RG, Barone FC, Medhurst AD, Luttmann MA, Giardina GAM, Hay DWP (2000) Nonpeptide tachykinin receptor antagonists. II. Pharmacological and pharmacokinetic profile of SB-222200, a central nervous system penetrant, potent and selective NK-3 receptor antagonist. J Pharmacol Exp Ther 295:373-381.

Schiltz JC, Hoffman GE, Stricker EM, Sved AF (1997) Decreases in arterial pressure activate oxytocin neurons in conscious rats. Am J Physiol Regul Integr Comp Physiol 273:R1474-R1483.

Shimokawa A, Kunitake T, Takasaki M, Kannan H (1998) Differential effects of anesthetics on sympathetic nerve activity and arterial baroreceptor reflex in chronically instrumented rats. J Auton Nerv Syst 72:46-54.

Schmidlin F, Roosterman D, Bunnett NW (2003) The third intracellular loop and caboxyl tail of neurokinin 1 and 3 receptors determine interactions with $\beta$-arrestins. Am J Physiol Cell Physiol 285:C945-C958.

Shughrue PJ, Lane MV, Merchenthaler I (1996) In situ hybridization analysis of the distribution of neurokinin-3 mRNA in the rat central nervous system. J Comp Neurol 372:395-414.

Sladek CD, Armstrong WE (1985) Neural pathways subserving osmotic control of vasopressin release. In: Vasopressin (Schrier R, ed), pp 435441. New York: Raven.

Sladek CD, Armstrong WE (1987) GABA antagonists stimulate vasopressin release from organ-cultured hypothalamo-neurohypophyseal explants. Endocrinology 120:1576-1580.

Sladek CD, Knigge KM (1977) Cholinergic stimulation of vasopressin release from the rat hypothalamo-neurohypophyseal system in organ culture. Endocrinology 101:411-420.

Smith DW, Day TA (2003) Catecholamine and oxytocin cells respond to hypovolaemia as well as hypotension. Neuroendocrinology 14:1493-1495.

Smith ME, Flynn FW (2000) Distribution of Fos-like immunoreactivity within the rat brain following intraventricular injection of the selective $\mathrm{NK}_{3}$ receptor agonist, senktide. J Comp Neurol 426:413-428.

Sorkin A, Von Zastrow M (2002) Signal transduction and endocytosis: close encounters of many kinds. Nat Rev Mol Cell Biol 3:600-614.

Spitznagel H, Baulmann J, Blume A, Unger T, Culman J (2001) c-Fos expression in the rat brain in response to substance $\mathrm{P}$ and neurokinin $\mathrm{B}$. Brain Res 916:11-21.

Stocker SD, Sved AF, Stricker EM (2000) Role of renin-angiotensin system in hypotension-evoked thirst: studies with hydralazine. Am J Physiol Regul Integr Comp Physiol 279:R576-R585.

Stricker EM, Verbalis JG (1986) Interaction of osmotic and volume stimuli in regulation of neurohypophyseal secretion in rats. Am J Physiol 250:R267-R275.

Takahashi K, Tanaka A, Hara M, Nakanishi S (1992) The primary structure and gene organization of human substance $\mathrm{P}$ and neuromedin $\mathrm{K}$ receptors. Eur J Biochem 204:1024-1033.

Takeda Y, Chou KB, Takeda J, Sachais BS, Krause JE (1991) Molecular cloning, structural characterization and functional expression of the human substance P receptor. Biochem Biophys Res Commun 179:1232-1240.

Warden MK, Young III WS (1988) Distribution of cells containing mRNAs encoding substance $\mathrm{P}$ and neurokinin $\mathrm{B}$ in the rat central nervous system. J Comp Neurol 272:90-113.

Watson PH, Fraher LJ, Natale BV, Kisiel M, Hendy GN, Hodsman AB (2000) Nuclear localization of the type 1 parathyroid hormone/parathyroid hormone-related peptide receptor in MC3T3-E1 cells: association with serum-induced cell proliferation. Bone 26:221-225.

Wells A, Marti U (2002) Signaling shortcuts: cell-surface receptors in the nucleus. Nat Rev Mol Cell Biol 3:1-6.

Whistler JL, Chuang H-H, Chu P, Jan LY, Von Zastrow M (1999) Functional dissociation of $\mu$ opioid receptor signaling and endocytosis: implications for the biology of opiate tolerance and addiction. Neuron 23:737-746. 